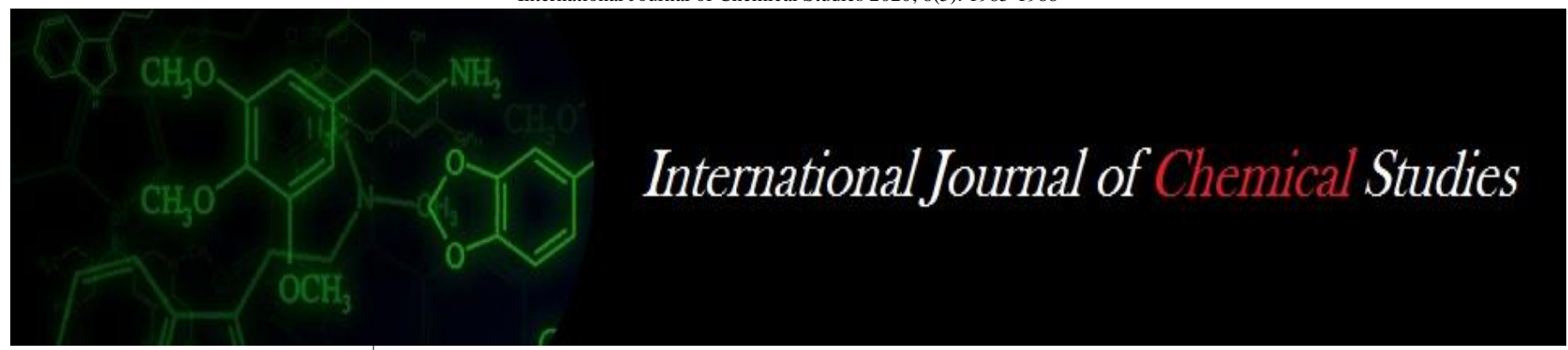

P-ISSN: 2349-8528

E-ISSN: 2321-4902

www.chemijournal.com

IJCS 2020; 8(5): 1985-1988

(C) 2020 IJCS

Received: 18-07-2020

Accepted: 22-08-2020

Gritta Elizabeth Jolly

Ph.D., Scholar, Department of

Agronomy, College of

Agriculture, Vellayani,

Trivandrum, Kerala, India

Sajitha Rani T

Professor and Head,

Instructional Farm, College of

Agriculture, Vellayani

Trivandrum, Kerala, India

Lekshmi Sekhar

Ph.D., Scholar, Department of

Agronomy, College of

Agriculture, Vellayani,

Trivandrum, Kerala, India

\section{The nitrogen content and nitrogen uptake efficiency of upland rice varieties under micro irrigation techniques}

\author{
Gritta Elizabeth Jolly, Sajitha Rani T and Lekshmi Sekhar
}

DOI: https://doi.org/10.22271/chemi.2020.v8.i5aa.10595

\begin{abstract}
A study was conducted at farm, College of Agriculture, Vellayani to assess the nitrogen content and nitrogen uptake efficiency of upland rice varieties under micro irrigation techniques in the summer of 2019. It was conducted in split plot design with the methods of irrigations as main treatments and varieties of rice as sub treatments. The main plot treatments consisted of:- $\mathrm{M}_{1}$ : Sprinkler irrigation at $100 \% \mathrm{PE}, \mathrm{M}_{2}$ : Sprinkler irrigation at $75 \% \mathrm{PE}, \mathrm{M}_{3}$ : Drip irrigation at $100 \% \mathrm{PE}, \mathrm{M}_{4}$ : Drip irrigation at $75 \%$ $\mathrm{PE}$ and $\mathrm{M}_{5}$ : check basin method of irrigation (using hose, which will be given thrice in a week based on evaporation loss) and the subplot treatments were:- $V_{1}$ : Prathyasa and $V_{2}$ : Uma. The study revealed that the grain and straw nitrogen concentration is the highest in the plots irrigated using check basin method. The grain nitrogen content in the variety Prathyasa, irrigated with check basin method was found to be the highest, compared to other treatments. The nitrogen uptake in grain was observed to be the highest in sprinkler irrigation at $100 \% \mathrm{PE}$ and was on par with drip irrigation at $100 \% \mathrm{PE}$, but significantly superior over check basin method of irrigation as well as drip irrigation and sprinkler irrigation at $75 \% \mathrm{PE}$. The nitrogen uptake in straw was also observed to be the highest in sprinkler irrigation at $100 \% \mathrm{PE}$, but was on par with drip irrigation at $100 \% \mathrm{PE}$ as well as check basin method of irrigation. The study revealed that the nitrogen content in grain and straw, as well as the nitrogen uptake in rice varies with the methods of irrigation as well as the genotypic differences.
\end{abstract}

Keywords: Pan evaporation, microirrigation, sprinkler, drip

\section{Introduction}

Food security is of serious concern nowadays because of the burgeoning population and decreasing land area. By 2050, the global population is expected to reach 9 billion and the food supplies are projected to be increased by 70-100\%. Rice (Oryza sativa L.) is the most important staple cereal crop in the world, feeding approximately half of the world population. Therefore, measures are to be taken to increase rice production significant enough to feed the growing world population. However, decreased arable land area, climate change, natural disasters, and frequent diseases and pest incidence have brought rice production under stress. As there is no further scope for arable land expansion, the only measure which can be adopted is to sustain yield improvement in existing land to meet the increasing food.

Application of nitrogen $(\mathrm{N})$ fertilizer is an effective way to improve crop yield, but it has considerable negative impacts on the environment as well. Steps are therefore to be taken to increase the yield, at the same time, decreasing applied $\mathrm{N}$ by maximizing the nitrogen use efficiency (NUE) of crops. Plant NUE is dependent upon N uptake, translocation, assimilation, and remobilization. Therefore enhancing the nitrogen uptake by crop is the first step in improving its nitrogen use efficiency. The loss of nitrogen from the soil can be by ammonia volatilization, denitrification, surface runoff and leaching in the soil-flood water system, thereby an expected increased loss from the rice fields. Reduction of nitrogen losses would increase both the soil and fertilizer nitrogen use efficiency and reduce environmental costs associated with denitrification and leaching of nitrates ${ }^{[1]}$. By enhancing the crop uptake of nitrogen, its loss to environment by various means can be reduced. Microirrigation practices can help reduce these losses to an extent, by enhancing the nitrogen uptake by the crop. With conventional irrigation, the excess water that moves through the profile can carry nitrate along with it, thereby losing a considerable amount by leaching with sprinkler or drip
Corresponding Author: Gritta Elizabeth Jolly Ph.D., Scholar, Department of Agronomy, College of Agriculture, Vellayani, Trivandrum, Kerala, India 
Irrigation, it is possible to control the amount of water applied to match crop evapotranspiration. It is also much easier to split the nitrogen applied into small doses during the irrigation season. Consequently, the nitrogen use efficiency may be substantially different with sprinkler and drip irrigation systems. Also, the best way to increase the $\mathrm{N}$ uptake capacity of the crop is to increase its growth rate ${ }^{[2]} . \mathrm{N}$ uptake varies with variation in genotypes as well ${ }^{[3]}$. The purpose of this study was to study the $\mathrm{N}$ uptake efficiency in two upland rice varieties grown under different irrigation methods viz., check border irrigation, sprinkler irrigation and drip irrigation.

\section{Materials and Methods}

The experiment was carried out in the farm, College of Agriculture, Vellayani during summer season of 2019. The maximum temperature of the region was observed to be $31.8^{\circ} \mathrm{C}$ and the minimum temperature was $21.8{ }^{\circ} \mathrm{C}$, with an average relative humidity of $93 \%$ and pan evaporation rate of $4 \mathrm{~mm}$ per day.

The experiment was conducted in split plot design with the methods of irrigation as the main plot treatments and varieties as the subplot treatments. The main plot treatments were:- $\mathbf{M}_{1}$ : Sprinkler irrigation at $100 \% \mathrm{PE}, \mathrm{M}_{2}$ : Sprinkler irrigation at $75 \% \mathrm{PE}, \mathrm{M}_{3}$ : Drip irrigation at $100 \% \mathrm{PE}, \mathrm{M}_{4}$ : Drip irrigation at $75 \% \mathrm{PE}$ and $\mathrm{M}_{5}$ : check basin method of irrigation (using hose, which will be given thrice in a week based on pan evaporation loss). The subplot treatments were:- $\mathrm{V}_{1}$ : Prathyasa and $\mathrm{V}_{2}$ : Uma. The pan evaporimeter reading for the entire duration of the crop was taken and the water requirement for all the treatments were quantified based on the pan evaporimeter readings, as given below: For drip irrigated plots, the following equation was used for quantifying the water requirement: Water requirement for one plot $=$ spacing $\mathrm{x}$ wetted area $\mathrm{x}$ No. of plants plot $^{-1} \mathrm{x}$ pan Evaporation Wetted area fraction for closely spaced crops is 0.7 For the treatments in which water is given at $75 \%$ PE, 75 percent of the water required from the aforementioned equation is taken. For sprinkler irrigated plot, the amount of water to be applied is calculated based on the discharge rates of the sprinkler head and the time for which the system has to be worked for the calculated amount of water to reach the soil is calculated on the basis of FAO calculator.

For hose irrigated plots, water was quantified using traditional bucket method, based on pan evaporation values.

The nitrogen content was estimated for grain and straw separately using Kjeldahl method for different treatments and it was multiplied with the grain yield and straw yield for various treatments separately to obtain the nitrogen uptake by grain and straw respectively. The nitrogen uptake efficiency was calculated using the formula:

$\mathrm{NUpE}=\mathrm{NUp} / \mathrm{Nav}$ (soil+fertilizer)

\section{Where}

NUpE $=$ Nitrogen uptake efficiency

NUp $=$ NUptake by straw/grain

Nav $=$ Nitrogen available

\section{Results and discussion}

Intermittent irrigation creates favourable soil physical, chemical and biological properties that support plant growth under mostly aerobic soil conditions, encouraging deeper rooting depth and creating favourable micro-climates in the soil, which support abundance of micro-organisms and more availability of micro-nutrients. Better root systems provide good anchorage for the plants and sustain effective use of applied fertilizers by checking losses from leaching [4]. The present study revealed that the grain nitrogen concentration is the highest in the plots irrigated using check basin method.
The grain nitrogen content in the variety Prathyasa, irrigated with check basin method was found to be the highest, compared to other treatments. The drip irrigated rice at $75 \%$ $\mathrm{PE}$ showed higher grain nitrogen content as compared to sprinkler irrigated at $100 \% \mathrm{PE}$ and $75 \% \mathrm{PE}$, as well as drip irrigated rice at $100 \% \mathrm{PE}$. The lowest grain nitrogen content was observed in treatment with sprinkler irrigation at $100 \%$ PE (Table 1). The nitrogen content in straw also showed a similar trend, as shown in the table 1. This is because, the crop $\mathrm{N}$ demand at any time of the crop cycle is the result of maximum crop mass and the critical plant $\mathrm{N}$ concentration, which is the minimum plant $\mathrm{N}$ concentration corresponding to maximum crop mass ${ }^{[5]}$. The actual plant $\mathrm{N}$ concentration in a crop stand declines even under favourable $\mathrm{N}$ supply as the crop mass increases ${ }^{[6]}$. The decline has been described empirically by a negative power function ${ }^{[7]}$ relating plant $\mathrm{N}$ concentration $(\% \mathrm{~N})$ to crop mass $\left(\mathrm{W}\right.$ in $\left.\mathrm{t} \mathrm{ha}^{-1}\right)$ as:

\section{$\% \mathrm{~N}=\mathrm{a} \mathrm{W}^{-\mathrm{b}}$}

The coefficient $a$ represents the plant $\mathrm{N}$ concentration for $\mathrm{W}=$ $1 \mathrm{t} \mathrm{ha}^{-1}$ Coefficient $b$ is dimensionless and it represents the ratio between the relative decline in plant $\mathrm{N} \%$ and the relative crop growth rate. In the study, the crop biomass was found to be the highest $\left(12.19 \mathrm{~kg} \mathrm{ha}^{-1}\right)$ in sprinkler irrigated plots at $100 \%$ PE of Prathyasa (Table 1), which lead to a decreased concentration of nitrogen by it. The treatments differed significantly in the grain nitrogen uptake, straw nitrogen uptake as well as the total biomass nitrogen uptake. The nitrogen uptake in grain was observed to be the highest in sprinkler irrigation at $100 \% \mathrm{PE}$ and was on par with drip irrigation at $100 \%$ PE, but significantly superior over check basin method of irrigation as well as drip irrigation and sprinkler irrigation at $75 \% \mathrm{PE}$. The nitrogen uptake in straw was also observed to be the highest in sprinkler irrigation at $100 \% \mathrm{PE}$, but was on par with drip irrigation at $100 \% \mathrm{PE}$ as well as check basin method of irrigation. Total biomass uptake showed a similar trend as in grain nitrogen uptake, with the highest in sprinkler irrigation at $100 \% \mathrm{PE}\left(126.24 \mathrm{~kg} \mathrm{ha}^{-1}\right)$ and the lowest $\left(99.25 \mathrm{~kg} \mathrm{ha}^{-1}\right)$ in check basin method of irrigation (Table 2). The optimum availability of soil moisture plays a key role in the processes of mineralization and solubilisation, affecting the availability and uptake of nutrients, and contributing to plant growth and yield. The low nitrogen uptake in check basin irrigated rice is due to the increased percolation and poor synchronisation between crop demand and availability of nitrogen, which can lead to leaching of the nitrate below the rooting zone ${ }^{[8]}$ (Anderson et al., 1998). Also, the root system if vigorous have early and fast growth and profuse proliferation to intercept and capture the $\mathrm{NO}^{3-}$ before it moves below the rooting depth ${ }^{[9]}$. The root system was best developed in the sprinkler irrigated rice plants, which resulted in better interception and capture of the $\mathrm{NO}^{3-}$. Also, the relationship between crop $\mathrm{N}$ uptake dynamics and LAI expansion is explained by the equation

\section{$\mathrm{N}=\mathrm{a}$ 'p LAI/k}

Plant $\mathrm{N}$ uptake is feedback regulated by shoot $\mathrm{N}$ and $\mathrm{C}$ signalling irrespective of the source of soil $\mathrm{N}^{[10]}$. A positive regulation comes from a $\mathrm{C}$ signal corresponding to photosynthetic assimilate transported by phloem from leaves to roots, and a negative signal comes from organic $\mathrm{N}$ recirculated from shoots to roots ${ }^{[11]}$. The LAI at $100 \% \mathrm{PE}$ sprinkler irrigation in the variety Prathyasa was found to be the highest (2.35), with the highest growth rate (Table 2). Thus, an increase in plant growth rate increases the leaf area and then the plant photosynthetic rate, leading to a positive $\mathrm{C}$ 
signal to the root transport system for nitrate absorption. The results were in confirmation with the study by Shock (2005) [12] whose observations showed that unlike in conventional methods of irrigation the relatively small increments of water added by micro irrigation practices like drip and sprinkler irrigation systems and careful irrigation scheduling, the soil profile is often not becoming saturated at $20 \mathrm{~cm}$ depth ${ }^{[12]}$.
These irrigation practices apparently allow a larger proportion of all available $\mathrm{N}$ sources to remain in the root zone. Residual nitrate and ammonium, a larger part of the fertilizer $\mathrm{N}$, and a larger part of any other $\mathrm{N}$ source are less apt to be leached. By using micro irrigation techniques, the substantial amounts of $\mathrm{N}$ are mineralized from soil organic matter and become available for plant growth ${ }^{[13]}$.

Table 1: The nitrogen content of straw and grain and grain yield and straw yield as influenced by methods of irrigations and varieties

\begin{tabular}{|c|c|c|c|}
\hline Treatments & $\mathrm{N}$ content grain & N content straw & Biomass yield \\
\hline \multicolumn{4}{|c|}{ Methods of irrigation (M) } \\
\hline $\mathrm{M}_{1}$ & 1.52 & 0.86 & 11.537 \\
\hline $\mathrm{M}_{2}$ & 2.08 & 1.08 & 7.542 \\
\hline $\mathrm{M}_{3}$ & 1.60 & 0.97 & 10.075 \\
\hline $\mathrm{M}_{4}$ & 2.11 & 1.17 & 6.679 \\
\hline $\mathrm{M}_{5}$ & 2.42 & 1.19 & 7.122 \\
\hline $\operatorname{SEm}( \pm)$ & 0.05 & 0.016 & 0.268 \\
\hline $\mathrm{CD}(0.05)$ & 0.156 & 0.049 & 0.834 \\
\hline \multicolumn{4}{|c|}{ Varieties (V) } \\
\hline $\mathrm{V}_{1}$ & 1.88 & 1.04 & 8.890 \\
\hline $\mathrm{V}_{2}$ & 2.01 & 1.07 & 8.292 \\
\hline $\operatorname{SEm}( \pm)$ & 0.018 & 0.007 & 0.086 \\
\hline $\mathrm{CD}(0.05)$ & 0.054 & 0.02 & 0.266 \\
\hline \multicolumn{4}{|c|}{ Interaction(M x V) } \\
\hline $\mathrm{M}_{1} \mathrm{~V}_{1}$ & 1.43 & 0.822 & 11.786 \\
\hline $\mathrm{M}_{\mathrm{I}} \mathrm{V}_{2}$ & 1.60 & 0.894 & 11.287 \\
\hline $\mathrm{M}_{2} \mathrm{~V}_{1}$ & 2.07 & 1.057 & 7.967 \\
\hline $\mathrm{M}_{2} \mathrm{~V}_{2}$ & 2.09 & 1.109 & 7.117 \\
\hline $\mathrm{M}_{3} \mathrm{~V}_{1}$ & 1.49 & 0.982 & 10.308 \\
\hline $\mathrm{M}_{3} \mathrm{~V}_{2}$ & 1.70 & 0.954 & 9.843 \\
\hline $\mathrm{M}_{4} \mathrm{~V}_{1}$ & 2.02 & 1.161 & 7.326 \\
\hline $\mathrm{M}_{4} \mathrm{~V}_{2}$ & 2.20 & 1.178 & 6.032 \\
\hline $\mathrm{M}_{5} \mathrm{~V}_{1}$ & 2.38 & 1.186 & 7.062 \\
\hline $\mathrm{M}_{5} \mathrm{~V}_{2}$ & 2.45 & 1.198 & 7.183 \\
\hline $\operatorname{SEm}( \pm)$ & 0.071 & 0.022 & 0.301 \\
\hline $\mathrm{CD}(0.05)$ & NS & 0.046 & 0.426 \\
\hline
\end{tabular}

$\mathrm{SE}=$ standard error $\mathrm{CD}=$ critical difference $\mathrm{NS}=$ non-significant

Table 2: The grain $\mathrm{N}$ uptake, straw nitrogen uptake, total biomass $\mathrm{N}$ uptake, leaf area index and Nitrogen uptake efficiency as influenced by the methods of irrigations and varieties

\begin{tabular}{|c|c|c|c|c|c|}
\hline Treatments & Grain N uptake & Straw N uptake & Total biomass $\mathrm{N}$ uptake & Leaf area index & Nitrogen Uptake Efficiency \\
\hline \multicolumn{6}{|c|}{ Methods of irrigation (M) } \\
\hline $\mathrm{M}_{1}$ & 59.93 & 66.31 & 126.24 & 2.24 & 41.51 \\
\hline $\mathrm{M}_{2}$ & 48.49 & 56.27 & 104.76 & 2.04 & 37.14 \\
\hline $\mathrm{M}_{3}$ & 59.40 & 61.07 & 120.47 & 1.86 & 40.35 \\
\hline $\mathrm{M}_{4}$ & 46.63 & 51.37 & 99.26 & 1.77 & 35.93 \\
\hline $\mathrm{M}_{5}$ & 50.70 & 59.80 & 110.50 & 1.70 & 38.28 \\
\hline $\mathrm{SE}(\mathrm{m} \pm)$ & 1.74 & 3.01 & 3.36 & 0.028 & 0.70 \\
\hline $\mathrm{CD}$ & 5.41 & 9.38 & 10.46 & 0.086 & 2.18 \\
\hline \multicolumn{6}{|c|}{ Varieties (V) } \\
\hline $\mathrm{V}_{1}$ & 55.35 & 59.14 & 114.50 & 1.97 & 39.11 \\
\hline $\mathrm{V}_{2}$ & 50.71 & 58.79 & 109.99 & 1.88 & 38.17 \\
\hline $\mathrm{SE}(\mathrm{m} \pm)$ & 0.55 & 0.95 & 1.00 & 0.009 & 0.21 \\
\hline $\mathrm{CD}(0.05)$ & 1.66 & NS & 3.05 & 0.027 & 0.63 \\
\hline \multicolumn{6}{|c|}{ Interaction (M xV) } \\
\hline $\mathrm{M}_{1} \mathrm{~V}_{1}$ & 63.61 & 62.62 & 126.23 & 2.35 & 41.50 \\
\hline $\mathrm{M}_{1} \mathrm{~V}_{2}$ & 56.25 & 70.00 & 126.25 & 2.13 & 41.51 \\
\hline $\mathrm{M}_{2} \mathrm{~V}_{1}$ & 51.44 & 57.81 & 109.26 & 2.03 & 38.05 \\
\hline $\mathrm{M}_{2} \mathrm{~V}_{2}$ & 45.53 & 54.73 & 100.26 & 2.05 & 36.24 \\
\hline $\mathrm{M}_{3} \mathrm{~V}_{1}$ & 63.49 & 59.35 & 122.85 & 1.90 & 40.86 \\
\hline $\mathrm{M}_{3} \mathrm{~V}_{2}$ & 55.32 & 62.79 & 118.10 & 1.81 & 39.84 \\
\hline $\mathrm{M}_{4} \mathrm{~V}_{1}$ & 50.68 & 55.88 & 106.57 & 1.80 & 37.46 \\
\hline $\mathrm{M}_{4} \mathrm{~V}_{2}$ & 42.57 & 46.85 & 91.93 & 1.74 & 34.39 \\
\hline $\mathrm{M}_{5} \mathrm{~V}_{1}$ & 47.54 & 60.04 & 107.57 & 1.76 & 37.69 \\
\hline $\mathrm{M}_{5} \mathrm{~V}_{2}$ & 53.86 & 59.57 & 113.99 & 1.65 & 38.88 \\
\hline $\mathrm{SE}(\mathrm{m} \pm)$ & 2.46 & 4.26 & 4.75 & 0.039 & 0.99 \\
\hline $\mathrm{CD}(0.05)$ & 3.78 & 6.59 & 6.96 & 0.061 & 1.44 \\
\hline
\end{tabular}

$\mathrm{SE}=$ standard error $\mathrm{CD}=$ critical difference $\mathrm{NS}=$ non-significant 


\section{Conclusions}

The nitrogen content in grain and straw, as well as the nitrogen uptake in rice varies with the methods of irrigation as well as the genotypic differences. As against the conventional methods of irrigation, the micro irrigation practices allow a larger proportion of $\mathrm{N}$ sources to remain in the root zone itself, and as relatively small increments of water is added by microirrigation practices, $\mathrm{N}$ sources are less likely to be leached, so that more of available $\mathrm{N}$ become available for plant growth. As less amount of nitrogen fertilizers are leached out in drip and sprinkler irrigation, it has significant environmental benefits also. Therefore by adopting micro irrigation practices, nitrogen losses to environment can be controlled to a good extent, thereby reducing nitrate pollution.

\section{Acknowledgement}

I am grateful for the support from Instructional farm, College of Agriculture, Vellayani for providing all the resources required for the conduct of the research, my major advisor Dr. T. Sajitha Rani and the Professors and colleagues of the Department of Agronomy, College of Agriculture, Vellayani for their support and valuable suggestions.

\section{Conflict of interest}

On behalf of all authors, the corresponding author states that there is no conflict of interest.

\section{References}

1. George T, Ladha JK, Buresh RJ, Garrity DP. Nitrate dynamics during the aerobic soil phase in lowland ricebased cropping systems. Soil Science Society of America Journal. 1993; 57:1526-1532.

2. Ortiz-Monasterio JI, Satre KD, Rajaram S, McMohan M. Genetic progress in wheat yield and nitrogen use efficiency under four nitrogen rates. Crop Sci. 1997: 37:898-904.

3. Borell A, Garisade AL, Fukai S, Reid DJ. Season nitrogen rate and plant type effect nitrogen uptake and nitrogen use efficiency in rice. Australian Journal of Agriultural Research. 1998; 49:829-843.

4. Stoop W, Uphoff N, Kassam A. A review of agricultural research issues raised by the system of rice intensification (SRI) from Madagascar: opportunities for improving farming systems for resource-poor farmers. Agricultural Systems. 2002; 71:249-274.

5. Greenwood DJ, Lemaire G, Goose G, Cruz P, Draycott A, Neetson JJ. Decline in percentage of N of C3 and C4 crops with increasing plant mass. Annals of Botany. 1990; 66:425-436.

6. Greenwood DJ, Neetson JJ, Draycott, A. Quantitative relationships for the dependence of growth rate of arable crops on their nitrogen content, dry weight and aerial environment. Plant and soil. 1986; 91:281-301.

7. Lemaire G, Salette J. Relation entre dynamique de croissanceet dynamique de prelenement d'azote par un pueplement de graminees fourageres. 1-Etude de I'effet dumilieu. Agronomie .1984; 4:423-430.

8. Anderson GC, Fillery IRP, Dolling PJ, Asseng S. Nitrogen and water flows for pasture-ley and lupin-wheat rotations in deep sands. Nitrogen mineralisation and utilisation. Australian Journal of Agriultural Research.1998; 49:329-343.

9. Liao MT, Fillery IRP, Palta JA. Early vigorous growth is a major factor influencing nitrogen uptake in wheat. Functional Plant Biology. 2004; 31:121-129.
10. Lemaire G, Millard P. An ecophysiological approach to modelling resources fluxes in competing plants. J Exp. Bot. 1999; 50:15-28.

11. Lejay L, Tillard, P, Lepetit M, Olive FD, Filleur S, Daniel F, Gojon A. Molecular and functional regulation of two nitrate uptake systems by $\mathrm{N}$ - and C- status of Arabidopsis plants. Plant J. 1999; 18:509-519.

12. Shock CC, Feibert EBG, Westermann D. "On farm" implementation of lower nitrogen fertilizer inputs through nitrogen accounting and validation of organic matter mineralization. Oregon State University Agricultural Experiment Station, Special Report .1998; 988:126-134.

13. Feibert EBG, Shock CC, Saunders LD. Nitrogen fertilizer requirements of potatoes using carefully scheduled sprinkler irrigation. Horticultural Science. 1998; 32:262265. 